\title{
UNFITNESS TO TEACH: CREDENTIAL REVOCATION AND DISMISSAL FOR SEXUAL CONDUCT
}

Dismissal from government employment for sexual behavior has been a subject of imcreasing concern to courts and commentators. While most of the literature and decisions have centered around dismissals of homosexuals, others-including a postal clerk living with a woman to wliom he was not married, ${ }^{1}$ a teacher who performed heterosexual acts at a "swingers" party, ${ }^{2}$ and a narried female schoolteacher who kept company with another $\operatorname{man}^{3}$ - have also been discharged from government einployment for off-duty sexual behavior.

This Comment discusses the revocation of California teaching credentials for sexual behavior. Part I outlines the statutory framework that requires revocation for "immoral" or "unprofessional" conduct and discusses the fitness-to-teach standard which was read into the statutes by the decision in Morrison v. State Board of Education. ${ }^{*}$ Part II catalogues the many reasons which have been advanced by courts, boards of education, and professional journals to justify the suspension of teachers who have engaged in socially or legally disapproved sexual behavior. The persuasiveness of these reasons is then appraised in the light of existing case law and social science data. Finally, this Comment suggests that only with the guidance of the standard laid down in Morrison can the courts deal more rationally and humanely with the difficult problems raised by teachers who have transgressed the bounds of conteinporary sexual mores.

\section{Morrison AND STATUTORY INTERPRETATION}

The California Education Code provides for revocation of the credentials of teachers convicted of certam sex crimes, ${ }^{5}$ felonies, ${ }^{0}$ crimes involving moral turpitude, ${ }^{7}$ and of teachers who have engaged in "im-

1. Mindel v. United States Civil Serv. Conım'n, 312 F. Supp. 485 (N.D. Cal. 1970). (1973).

2. Pettit v. State Bd. of Educ., 10 Cal. 3d 29, 513 P.2d 889, 109 Cal. Rptr. 665

3. Schwer's Appeal, 36 Pa. D. \& C. 531 (C.P. of Clinton County 1939).

4. 1 Cal. 3d 214, 461 P.2d 375, 82 Cal. Rptr. 175 (1969), noted in 59 Calir. L. REv. 58 (1971).

5. CaI. EDUu. Code $\S \S 12912,13207$ (West Supp. 1972).

6. Id. $\S 13403(\mathrm{~h})$. Conviction of one of the crimes enumerated in $\S 12912$ is sufficient proof of moral turpitude to warraut revocatiou under $\$ 13403(\mathrm{~h}) . I d$. $\S 12911$.

7. Id. $\S 13403(\mathrm{~h})$. 
moral" or "unprofessional" conduct. ${ }^{8}$ Conviction of a crime specifically enumerated in the code makes a teacher hable to automatic credential revocation with no prior administrative hearing. ${ }^{9}$ Where a teacher is convicted of a crime not specified in the code, the local board of education or the State Commissioner of Education may seek credential revocation when, in their opinion, the crime involves moral turpitude. $^{10}$ Revocation of a teacher's credential may also be sought for immoral or unprofessional conduct not involving conviction of any crime. ${ }^{11}$

In Morrison v. State Board of Education ${ }^{12}$ the California Supreine Court held that the terms "immoral" and "unprofessional conduct" do not render Education Code section $13202^{13}$ void for vagueness so long as they are construed to apply only to conduct indicating unfitness to teach. ${ }^{14}$ Morrison's teaching credentials had been revoked because the State Board of Education had found that a noncriminal homosexual escapade ${ }^{15}$ in which he had participated constituted immoral and unprofessional conduct. The court held that revocation of credentials for immoral or unprofessional conduct is permissible under the statute only if it can be shown that the teacher's retention in the profession poses a significant danger of harm to students, school employees, or others who might be affected by his actions as a teacher. ${ }^{16}$

Even before Morrison, the California Supreme Court had stated that the purpose of license revocation is not punishinent of the licensee

8. Id. $\S 13403(\mathrm{a})$.

9. Id. § 13206; Di Genova v. State Bd. of Educ., 45 Cal. $2 \mathrm{~d} 255,288$ P.2d 862 (1955). As stated in Slaughter v. Edwards, 11 Cal. App. 3d 285, 294, 90 Cal. Rptr. 144,150 (1st Dist. 1970), no hearing is required because:

In such cases there is no real necessity to examine the facts, resolve any conflicts in the evidence, and exercise any judgment with respect thereto, but the only question is a legal one, i.e., whether the licensee was convicted of a crime of the character specified in the statute. In these cases due process is satisfied because the ticensee had his day in court when he was put to trial for and convicted of [the crime]. (Citations omitted).

See also Purifoy v. State Bd. of Bduc., 30 Cal. App. 3d 187, 192, 106 Cal. Rptr. 201, 204 (1st Dist. 1973).

10. CaL. Educ. Code $\S \S 13403$ (h), 13404 (West Supp. 1972).

11. E.g., Goldsmith v. Board of Educ., 66 Cal. App. 157, 225 P. 783 (3d Dist. 1924).

12. 1 Cal. 3d 214, 461 P.2d 375, 82 Cal. Rptr. 175 (1969).

13. CaL. Educ. Code $\$ 13202$ (West Supp. 1972).

14. 1 Cal. $3 \mathrm{~d}$ at $218,461 \mathrm{P} .2 \mathrm{~d}$ at $377,82 \mathrm{Cal}$. Rptr. at 177.

15. Though the opinion does not disclose the exact nature of the conduct, it appears that Morrison engaged in mutual masturbation with another male. See Amundson v. State Bd. of Educ., 2d Civ. No. 37942 at 7 n.2 (Cal. Ct. of App. 2d Dist., Div. 5, filed Dec. 17, 1971); Comment, The Good Moral Character of California Administrative Agencies-A Study of the Good Moral Character Requirement, 5 U.C. Davis L. Rev. 84, 95 n.7 (1972).

16. 1 Cal. 3d at 235, 461 P.2d at 391, 82 Cal. Rptr. at 191. 
but the protection of the public. ${ }^{17}$ For teacher credential revocation, Morrison equated this interest with the need to remove from the teaching profession those whose conduct demonstrates that they are unfit to teach. ${ }^{18}$ Unfitness to teach, in turn, is defimed in two ways. A teacher may be removed if "his retention . . . poses a significant danger of harm to either students, school employees, or others who might be affected by his actions as a teacher,"10 or, if he or she demonstrates an impaired ability to teach. ${ }^{20}$ In either case, sexual behavior (apart from those statutory crimes where dismissal is automatic) is initially presumed irrelevant to a teacher's qualifications; to establish the requisite relationship between sexual behavior and unfitness to teach, more is needed than a bare citation of disapproved conduct. Morrison's reinstatement was ordered because there was no showing that his single non-criminal lomosexual contact posed a danger of harm to students or fellow employees, or that his actions or the publicity surrounding the event substantially impaired his ability to teach. ${ }^{21}$

In cases decided since Morrison, the California courts of appeal have disagreed over the meaning of the "fitness-to-teach" standard read into Education Code section 13202 by that decision. ${ }^{22}$ In a recent case, Pettit v. Board of Education, ${ }^{23}$ the California Supreme Court attempted to give content to the Morrison fitness-to-teach test. While Pettit can be read as an effort to clarify the implications of Morrison, the majority opinion left many serious questions unanswered, and, by attempting to distinguish Morrison on its facts, weakened many of the broad implications of that decision. This and the division among appellate courts and resulting uncertainty over the proper interpretation of the statutory standard established in Morrison make it important to clarify what the relationship is between fitness to teach and sexual behavior.

II

\section{Defining the Harm Threatened by Sexual Unorthodoxy}

Several varieties of harm have been suggested to justify dismissal

17. See, e.g., Yakov v. Board of Med. Exaininers, 68 Cal. 2d 67, 435 P.2d 553, 64 Cal. Rptr. 785 (1968).

18. 1 Cal. 3d at 235, 461 P.2d at 391, 82 Cal. Rptr. at 191.

19. Id.

20. Id.

21. Id. at 235-37, $461 \mathrm{P} .2 \mathrm{~d}$ at 391-93, 82 Cal. Rptr. at 191-93.

22. E.g., Alford v. Department of Educ., 13 Cal. App. 3d 884, 889, 91 Cal. Rptr. 843, 846 (2d Dist. 1970) (limiting Morrison's application to private noncriminal sexual conduct); Pettit v. State Bd. of Educ., 2d Civ. No. 39637 at 7 (Cal. Ct. of App., 2d Dist., Div. 3, filed Sept. 28, 1972) (interpreting Morrison to require strict scientific proof that retention of the teacher would result in harm to the school community).

23. 10 Cal. 3d 29, 513 P.2d 889, 109 Cal. Rptr. 665 (1973). 
of teachers who have engaged in disapproved sexual conduct: ${ }^{24}$

1. That certain sexual conduct is immoral per se.

2. That an episode of sexual misconduct suggests a potential for misbehavior with students.

3. That the notoriety generated by disclosure of the conduct will interfere with school functioning, either by impairing the teacher's relationships with his co-workers, interfering with the teacher's ability to command respect and discipline from his or her students, or destroying the public's confidence in the school systenn.

4. That the teacher's sexual orientation, even if not revealed publicly, will be subconsciously perceived and internalized by his or her students.

The validity of each of these as a basis for dismissal must be examined in the context of the underlying justification for credential revocation as stated in Morrison - unfitness to teach.

\section{A. Unorthodox Sexual Conduct as Immoral Per Se}

The California courts first explored the relationship between homosexual behavior and fitness to teach in Sarac $v$. Board of Education.25 A teacher, Sarac, was convicted for soliciting two undercover policemen to engage in homosexual acts at a public beach. Revocation of his credentials was sought by the State Board of Education. In its review of the revocation, the court of appeals held that because homosexuality is highly offensive to most citizens it constitutes immoral conduct amounting to unfitness to teach within the meaning of the Education Code. The court declared that "[h]omosexual behavior has long been contrary and abhorrent to the social mores and moral standards of the people of California as it has been smce antiquity to those of many other peoples."26

Other courts have reiterated this equation of homosexuality with immorality. In Schlegel v. United States, ${ }^{27}$ the court upheld the dismissal of a government employee for engaging in acts of homosexual mutual masturbation with another man in a private home. Explaining that the dismissal was necessary to prevent adverse effects on the efficiency of public service, ${ }^{28}$ the court summarized its analysis with the remark that "any school boy knows that a homosexual act is immoral, indecent, lewd, and obscene." ${ }^{29}$

24. See generally, Comment, Homosexuals in Government Employment: The Boys in the Bureau, 3 SETON Hall L. Rev. 89, 98 (1971).

25. 249 Cal. App. 2d 58, 57 Cal. Rptr. 69 (2d Dist. 1967).

26. Id. at 63, 57 Cal. Rptr. at 72.

27. 416 F.2d 1372 (Ct. Cl. 1969).

28. Id. at 1378; see text accompanying notes 47-53 infra.

29. 416 F.2d at 1378 . 
Unfitness and homosexuality have also been linked by behavioral scientists who believe that homosexuality is evidence of arrested development. ${ }^{30}$ As a result of having failed to develop a fully adult personality, homosexuals tend to be egocentric, insincere, and lacking in emotional stability, ${ }^{31}$ qualities obviously mconsistent with being a good classroom teacher. This view, however, has been sharply criticized by those behavioral scientists who see homosexuality as simply one of many forms of sexual expression, none of which is intrinsically better than any other. ${ }^{32}$ Simce there is little agreement on the fundamental premise that homosexuality and fitness are related, it would seem better to resolve the question of a teacher's emotional suitability for teaching by examining his or her performance in the classroom rather than his or her preference for sexual partners. Indeed, in Morrison the court rejected a simplistic equation of lromosexuality and unfitness to teach. Overruling that part of Sarac that suggested that homosexual conduct itself justifies dismissal, the court held that sexual unorthodoxy, however "immoral" in the eyes of many, does not, without more, warrant exclusion from the teaching profession. To be a vahid basis for dismissal, conduct must be shown to affect the teacher's fitness to teacli. ${ }^{33}$

\section{B. Potential for Misconduct with Students}

Revocation of the credentials of teachers engaging in consensual sexual activity with other adults is sometimes justified by the danger of their misconduct with students. One California appellate court ${ }^{34}$ has even read Morrison as implying that the potential for misconduct with students is a sufficient ground for discharge whenever a teacher can be shown to havc engaged in any kind of sexual misconduct. This interpretation does not reflect an accurate reading of that opimion. In Morrison the school board's findings of unfitness were rejected by the

30. W. PARKER, Homosexuals and EMPloYMent 10 (1970).

31. A. Watson, Psychiatry for LAwyers 196-205 (1968); Cf. Mrtchell, The HoMOSEXUAI AND THE LAW 15 (1969); See also Note, Government Created Employment Disabilities of the Homosexual, 82 HaRv. L. REv. 1738, 1742-43 (1969); Note, Security Clearances for Homosexuals, 25 STAN. L. REv. 403, 414 n.79 (1973).

32. B. KarppMan, The SeXual OFFender and His OfFenses 155-56 (1959); Great Britain, Committee on Homosexual Offenses and Prostitution, The WolfENDEN REPORT 30-36 (Amer. ed. 1963); Comment, Homosexuals in Government Employment: The Boys in the Bureau, 3 SETON HALI L. REv. 89, $98-99$ (1971); Note, Security Clearances for Homosexuals, 25 Stan. L. Rev. 403, 414 (1973); Cf. Adams v. Laird, 420 F.2d 230, 241 (D.C. Cir. 1969) (Wright, J., dissenting), cert. denied, 397 U.S. 1039 (1970).

33. 1 Cal. 3d at $225,238,461$ P.2d at $382-83,393,82$ Cal. Rptr. at 182-83, 193. Of course the principle should be equally applicable to sexual behavior other than homosexuality.

34. Board of Trustees v. Stubblefield, 16 Cal. App. 3d 820, 94 Cal. Rptr. 318 (2d Dist. 1971). 
court precisely because there was no evidence that Morrison was more likely than the average adult male to engage in forbidden conduct with students. $^{35}$ Where potential misconduct with students is at issue, there must be evidence supporting a probability of misconduct greater than that expected of the general adult population. Where this evidence is absent, courts must refrain from unfounded speculations about an individual's future conduct. ${ }^{38}$

Some indication of the difficulty of establishing such a probability can be inferred from the scarcity of reported decisions upholding revocation on this ground. Since Morrison, only one decision has dealt with the issue of potential misconduct with students. In Board of Trustees v. Stubblefield, ${ }^{37}$ a male junior college teacher was found at night, in a parked car, with a female student. ${ }^{38}$ Both were partially undressed - a graphic demonstration of potential for misconduct with students. Needless to say, most cases are not this clear. Indeed, a major difficulty with the potential-for-misconduct test is that it simply is not self-evident that a teacher who engages in consensual behavior with another adult is more likely than other teachers to seduce or molest children. ${ }^{39}$ Homosexuals who teach may even be more likely than the average adult to practice discretion in their choice of sexual partners simce they have more to lose should their conduct come to hight. Thus, without empirical evidence that homosexuals (or others whose sexual behavior is singled out for criticism) are more likely than others to attempt to seduce or "convert" the students in their charge, ${ }^{40}$ a teacher's private

35. 1 Cal. 3d at 236, 461 P.2d at 392, 82 Cal. Rptr. at 192. While Morrison appears to speak of probabilities for misconduct, Stubblefield, without citation to Morrison, interprets the case as placing paramount importance on the possibility of impairmeut of teaching ability. $16 \mathrm{Cal}$. App. 3d at 825, $94 \mathrm{Cal}$. Rptr. at 322.

36. 1 Cal. 3d at 236-37, 461 P.2d at 391-93, 82 Cal. Rptr. at 191-93.

37. 16 Cal. App. 3d 820, 94 Cal. Rptr. 318 (2d Dist. 1971).

38. 16 Cal. App. 3d at 823,94 Cal. Rptr. at 320.

39. See Note, 59 CALIF. L. REv. 64 (1971). It is interesting to note that in all the literature relating to the hazards homosexuals pose to young children, there is little mention of the dangers of exposing young girls to the influence of heterosexual male teachers. "The assunption seems to be that the latter are better able to control their pedophilic tendeucies. The facts do not warrant such fears. The great majority of homosexual males have no more sexual interest in young boys than the great majority of heterosexual males have in young girls." Pomeroy, Homosexuality, in THE SAME SEx 3, 11 (R. Weltge, ed. 1969).

40. But see Pettit, 10 Cal. 3d at 31 n.1, 513 P.2d at 890 n.1, 109 Cal. Rptr. at 666 n.1. The superintendeut testified at the revocation hearing that Pettit might even inject her ideas of sexual morals into the classroom. The court appears to have considered such testimony significant [see text accompanying notes 85 \& 86 infra] perhaps signalling that the "more likely than others" test in Morrison may apply only to actual or attempted physical contacts with students. This limitation of Morrison seems both unwarranted and unsound. A child's sexual development is likely to be altered less by advocacy of unorthodox sexual behavior than by seduced or enticed participation in such behavior. Because the harm is greater, the proof sufficient to show that one 
sexual behavior should not be taken as evidence of unfitness to teach under the potential-misconduct rationale.

\section{Notoriety and Its Effect on the Community}

On learning of a teacher's sexual conduct, co-workers, parents, students, or members of the community may object to his retention. Often the rationale for dismissal is stated in terms of impairment of fitness for service because public knowledge of the teacher's behavior will adversely affect his relationships with co-workers or cause embarrassment to the school system. ${ }^{41}$ In Morrison, however, the court indicated that public awareness of a teacher's conduct was a valid basis for dismissal only to the extent that it seriously jeopardized his ability to teach. If the notoriety surrounding the behavior so injures the teacher's image as to render him incapable of performing effective service, it could be a basis for revocation even where no potential for misconduct with students exists. ${ }^{42}$

In Pettit v. Board of Education, the majority invoked the notoriety doctrine as a partial rationale for upholding revocation and dismissal. ${ }^{43}$ Pettit had participated in two televised discussions of unconventional sexual life-styles. Although Pettit appeared on the program wearing a disguise, she was recognized by a fellow teacher who apparently informed other teachers and administrators of Pettit's television appearances and her statements approving spouse-swapping and group sex. By choosing to regard notoriety as conclusive, Pettit seems to have ignored the holding of Morrison that notoriety is only a means of giving content to the fitness requirement. ${ }^{44}$ The court cited no evidence in the record that knowledge on the part of a few teachers and administrators of Pettit's televised comments in any way interfered with her teaching effectiveness. No evidence was offered to show that knowledge of her conduct had come to the attention of parents or students. Nor was there any showing that her working relations with colleagues or classroom performance had suffered. Indeed, the majority did not even argue that such ill effects were likely to occur. ${ }^{45}$ Certainly the

teacher is more likely than others to engage in misconduct with students should be less, not more, than that necessary to show that he or she is likely to advocate disapproved sexual behavior to students.

41. See generally Norton v. Macy, 417 F.2d 1161 (D.C. Cir. 1969).

42. $1 \mathrm{Cal} .3 \mathrm{~d}$ at $237,461 \mathrm{P} .2 \mathrm{~d}$ at $392,82 \mathrm{Cal}$. Rptr. at 192. That there was no "public" awareness of Morrison's conduct was one reason the court ordered reinstatement. See text accompanying note 21 supra.

43. 10 Cal. $3 \mathrm{~d}$ at $34-35,513$ P.2d at 893,109 Cal. Rptr. at 669 .

44. 1 Cal. 3d at 237, 461 P.2d at 392, 82 Cal. Rptr. at 192.

45. The only ill effects "likely" to occur, according to administrators at the revocation hearing, were that Pettit "would be unable to set a proper example for her pupils or to teach moral principles to them." Pettit, $10 \mathrm{Cal}$. 3d at $31 \mathrm{n} .1,513 \mathrm{P} .2 \mathrm{~d}$ at $890 \mathrm{n} .1,109$ Cal. Rptr. at $661 \mathrm{n} .1$. See discussion in text accompanying notes 115-119 infra. 
Morrison requirement that notoriety relate to teaching effectiveness can not be met merely by declaring that conduct has become notorious without relating the notoriety to its impact, if any, on the teaching situation. Other decisions have established this principle in a wide variety of employment cases. For example, in Norton v. Macy, ${ }^{46}$ an earlier federal case, the court considered the effect that notorious conduct may liave, both on co-workers and the public. Norton, a budget analyst for N.A.S.A., liad made a homosexual advance to another male while off duty. Citing Kinsey's observation that 37 percent of American males liave had at least one homosexual contact during their lifetime, the court noted that the government must be carrying many sucl employees on its rolls without noticeable impairment of efficiency or public image. ${ }^{47}$ The court accepted the government's argument that when the potential for embarrassment to the agency is great, dismissal can be predicated on potential, rather than actual notoriety. ${ }^{48}$ Nevertheless, on the facts before it, the court found the potential for notoriety to be minimal because of the infrequency of the conduct (four incidents during a period of several years) and the private character of the actions, and Norton was ordered reinstated. ${ }^{49}$

Although employers may take into account the reactions of other employees and the public in determining whether efficiency will be adversely affected, they must prove a specific and substantial connection between the conduct and the alleged loss of efficiency. ${ }^{50}$ In Norton, the court gave an example of such a "specific cormection" in a lyypothetical case in which an employee's financial unreliability is alleged as grounds for dismissal:

[T] he anticipated discredit to the agency from [his] financial delinquency is discredit with a specific sector of the public [creditors] which may have an ascertainable effect on the agency's ability to perform its duties. ${ }^{51}$

Public service might be mjured in two ways. First, creditors might hound supervisors in an attempt to pressure employees to pay their bills. $^{62}$ And, second, creditors might become reluctant to extend credit to government workers (who are exempt from wage attachment) making government service a less attractive career. ${ }^{53}$ Both effects would

46. 417 F.2d 1161 (D.C. Cir. 1969).

47. Id. at 1167.

48. Id.

49. Id.

50. Id. at 1166. But see Schlegel v. United States, 416 F.2d 1372, 1378 (Ct. C1. 1969) (efficiency will inevitably suffer when honıosexuals are permitted to remain in government service once detected).

51. 417 F.2d at 1168 .

52. $1 d$.

53. Id. 
obviously impair the service's ability to perform its work efficiently.

In the teaching profession, the requisite specific connection between notoriety and effect on ability to teach might flow from the abhorrence with which certain forms of sexual behavior are regarded by some segments of the public. Homosexuality, for example, is regarded as morally harmful by a large percentage of Americans. ${ }^{54} \mathrm{Re}-$ tention of known homosexuals, it might be argued, would invite public disapproval of the school or school system solely because of the scliool's association with a homosexual. Co-workers might become resentful or antagonistic thus making administrative and collegial relations unproductive. Parents might lose faith in the school system. Voters might reject scliool bonds necessary to supply criticially needed funding. Moreover, it can be argued that refusal to lionor community and parental sentiments by dismissal of the offending teacher can lead to erosion of trust and support for the educational system, in turn adversely affecting the learning process in the schools. ${ }^{65}$

While such arguments may be made to establish a connection between the teacher's sexual conduct and the quality of his relationships with co-workers or the public, it is doubtful that such considerations deserve much weight in dismissal decisions. Merely to avoid embarrassment, school districts certainly could not exclude persons of a particular race, religion, or political persuasion. While sexual preferences lave not yet been cliaracterized as requiring the saine protection as these more traditional interests, the courts have in recent years protected human privacy, ${ }^{\text {b6 }}$ particularly when its invasion is sought to be made a condition of employment. ${ }^{57}$ At a minimum, "[ $\left.t\right]$ lie power of the state to regulate professions and conditions of employment must not arbitrarily inpair the right of the individual to live his private life, apart from his job, as he deems fit." ${ }^{28}$ As the court concluded in Morrison, "[t]he right to practice one's profession is sufficiently precious to surround it with a panoply of legal protection."

54. Trme, Oct. 31, 1969, at 56. See also Sexuality, Psychology Today, Sept. 1973 , at 17-18, reporting that 84 percent of the public finds homosexuality "obscene and vulgar."

55. Comment, Teacher Dismissal Legislation: The Nevada Approach, 6 HARv. J. LEGIS. 112, 121 (1968).

56. E.g., Griswold v. Connecticut, 381 U.S. 479 (1965).

57. Morrison, 1 Cal. 3d at 239, 461 P.2d at 394, 82 Cal. Rptr. at 194. See also Mindel v. United States Civil Serv. Comm'n, 312 F. Supp. 485 (N.D. Cal. 1970) in which the court held that the federal government may not condition eniployment on waiver of rights of privacy. (Postal clerk living with a wonian to whom he was not married.)

58. Morrison, 1 Cal. 3d at 239, 461 P.2d at 394, 82 Cal. Rptr. at 194.

59. Id., quoting Yakov v. Board of Med. Examiners, 68 Cal. 2d 67, 75, 435 P.2d 553, 559, 64 Cal. Rptr. 785, 791 (1968). 
Having characterized the individual interests at stake as "the right of the individual to live his private life" and "the right to practice one's profession," the court should go on to weigh these ${ }^{60}$ against the school's interest in preserving its public image. In striking a balance in individual cases, courts may validly assess the degree to which the teacler's actions invited notoriety (for example by "flaunting"11 or "careless displaying" ${ }^{32}$ ) or involved public advocacy of deviant behavior. ${ }^{63}$ In doing so, the courts should probably take into account such factors as the age of the children ${ }^{64}$ and the subject matter taught. ${ }^{65}$ Teachers of very young or adolescent children, and those who teach subjects pertaining to sexual activity might well be subjected to a higher standard of scrutiny. ${ }^{66}$ Where none of these factors is present, lowever, the court might well reject the alleged harm of notoriety as nothing "more concrete . . . than a general tarmishing on an agency's image."

60. Cf. id. 1 Cal. 3d at 229, 461 P.2d at 386, 82 Cal. Rptr. at 186. See also Comment, Government Employment and the Homosexual, 45 ST. JoHN's L. Rev. 303, 310 (1970).

61. Morrison, 1 Cal. 3d at 237, 461 P.2d at 393, 82 Cal. Rptr. at 193; Norton v. Macy, 417 F.2d 1161, 1167 (D.C. Cir. 1969).

62. Morrison, 1 Cal. 3d at 237, 461 P.2d at 393, 82 Cal. Rptr. at 193. But cf. Pettit where the conrt characterized as "semi-pnblic" sexual acts performed at a swingers' party and held that the teacher's "flagrant display indicated a serious defect of moral character, normal prudence and good common-sense," justifying the conclnsion that she "lacked the minimum degree of discretion and regard for propriety expected of a public school teacher." 10 Cal. 3d at 35, 513 P.2d at 893, 109 Cal. Rptr. at 669. Pettit's lack of discretion or commonsense hardly bears on the issue of notoriety unless the court was drawing the questionable inference that Pettit's behavior was evidence of a propensity for notorious conduct. It is doubtful that the court was concerned with what Pettit's fellow swingers might think of teachers or the educational system.

63. See McConnell v. Anderson, 316 F. Supp. 809 (D. Minn. 1970). See also Pettit where the court called attention to the teacher's two television appearances. $10 \mathrm{Cal}$. 3d at 35, 513 P.2d at 893, 109 Cal. Rptr. at 669. Although Pettit was disguised, apparently her nnconventional attitudes became known to a few teachers and adininistrators. See text accompanying notes 43-44 supra. That such a limited group could connect the views with a particular individual should not necessarily be evidence of notoriety, a word generally used to refer to one widely and unfavorably known. Further, evidence of notoriety is meaningful only if it is likely to render the "notorious" teacher ineffective in his professional capacity. See discussion accompanying note 42 supra.

64. See McConnell v. Anderson, 316 F. Supp. 809, 814 (D. Minn. 1970).

65. This was a factor thought inportant by the Pettit court of appeals. Pettit v. Board of Ednc., 2d Civ. No. 39637, at 10 (Cal. Ct. of App., 2d Dist, Div. 3, filed Sept. 28, 1972). See also text accompanying notes $87-92$ infra for additional discussion of factors to be considered in balancing interests.

66. See generally. Pettit, $10 \mathrm{Cal}$. 3d at $41,513 \mathrm{P} .2 \mathrm{~d}$ at 898, $109 \mathrm{Cal}$. Rptr. at 674 (Tobrimer, J., dissenting). It seems plausible, however, that very young children might be least affected by hearing, for example, that a teacher was "a homosexual." Because the term may have no meaning for young children, the primary potential for harm would be the pejorative tone by which the information was conveyed.

67. Norton, 417 F.2d at 1168. 


\section{Public Versus Private Conduct}

Whether objectionable conduct has taken place in public or private has been considered relevant by some courts in assessing the degree of notoriety. In Mindel v. United States Civil Service Commission, $^{68}$ the court ordered reinstatement of a postal clerk who had been dismissed for living with a woman out of wedlock. The opinion declared that the right to privacy guaranteed by the ninth amendment forbids termination of employment for reasons relating to a worker's private sex life. ${ }^{69}$ The court ruled that the Post Office had failed to show a rational, mucl less a compelling reason for requiring Mindel to live according to its special code of behavior. ${ }^{70}$ Similarly, in Norton, the court invoked the due process clause to limit government discretion when dismissal is based on intrusion into constitutionally protected areas of privacy. ${ }^{71}$ The court declared that a federal bureaucracy could not impose majoritarian codes of conduct on the private lives of government employees without violating "elementary concepts of liberty, privacy, and diversity."72 More recently, the Morrison court eclioed the Norton decision when it stated that a governmental agency could not dismiss an employee merely because it disapproved of his "personal, private conduct."73

In Moser v. State Board of Education, ${ }^{74}$ however, the court upheld revocation of the credential of a teacher convicted of a misdemeanor (disturbing the peace) stemming from a homosexual act performed in a public rest room. ${ }^{75}$ The court distinguished both Morrison and Norton as applying only to private conduct. Despite Morrison's disapproval of the sweeping language of Sarac, ${ }^{76}$ in Moser the court insisted that Sarac was undisturbed in its essential holding that evidence of homosexual behavior in a public place constituted proof of unfitness for service in the public schools. ${ }^{77}$ This seems to fly in the face of Morrison's ruling that notoriety can support dismissal only if it is so extreme that it demonstrably impairs the teacher's ability to command respect, or to function effectively with other members of

68. 312 F. Supp. 485 (N.D. Cal. 1970).

69. Id. at 488 .

70. Id.

71. 417 F.2d at 1164, citing Stanley v. Georgia, 394 U.S. 557 (1969), and Griswold v. Connecticut, 381 U.S. 479 (1965).

72. Id. at 1165 .

73. 1 Cal. 3d at 225, 461 P.2d at 382, 82 Cal. Rptr. at 182.

74. 22 Cal. App. 3d 988, 101 Cal. Rptr. 86 (2d Dist. 1972).

75. Id. at 990,101 Cal. Rptr. at 87.

76. 1 Cal. 3d at 238, 461 P.2d at 393, 82 Cal. Rptr. at 193.

77. 22 Cal. App. 3d at 992, 101 Cal. Rptr. at 88. The Moser court also stressed that Moser had committed a criminal offense while Morrison had not been charged with a crime. See notes 94-112 infra and accompanying text. 
the school staff, thereby impairing his or her fitness to teach.

Subsequently, the simplistic public-private analysis employed in Moser to distinguish Morrison received a measure of legitimacy in Pettit v. State Board of Education..$^{78}$ In Pettit, the California Supreme Court upheld the dismissal of a female teacher convicted of outraging public decency. Her conviction was for participating in three acts of heterosexual oral copulation at a "swingers" party attended by about 20 persons at a private home. ${ }^{79}$ Although the only witnesses were adults who had come specifically to watch and engage in such actions, the court held that the woman's conduct had been "semi-public."80 This characterization was most unfortunate. If the reason for proscribing the performance of sexual acts in public is that passersby miglit be forced to view them against their will, and sexual behavior is performed in a place where no one can be offended, ${ }^{81}$ dismissal is not necessary to vindicate that interest. If, on the other hand, the interest alleged to be vindicated by the public-private distinction is unfitness flowing from notoriety, the sympathy of the witnesses (who are unlikely to consider their own conduct scandalous) diminisles the possibility that the public will know of the conduct.

One decision, Amundson v. State Board of Education, ${ }^{82}$ has avoided the weaknesses of the public-private distinction relied on by Moser and Pettit. In that case the court leeld that, in itself, public solicitation of homosexual acts has at inost a "neutral effect" to teach. Although it found that the parties contemplated performing the acts on public premises, the court felt the conduct was not so indiscreet as to invite the kind of publicity that could impair Amundson's ability to function as a teacher. ${ }^{84}$ By focusing on the possible impact on the teacher's fitness to teach rather than on the public-private nature of the conduct, Amundson sets a sound pattern for other courts to follow in implementing the guidelines laid down in Morrison.

As Amundson indicates, it does not serve the fitness-to-teach standard of Morrison to predicate revocation solely on the degree to which the offending behavior is public or private. While acts committed in public may, perhaps, have a tendency to acquire greater notoriety than acts performed in secret, it is a mistake to equate notoriety with the public or private circunstances under which the sexual behavior

78. 10 Cal. 3d 29, 513 P.2d 889, 109 Cal. Rptr. 665 (1973).

79. Id. at 30-31, 513 P.2d at 890, 109 Cal. Rptr. at 666 .

80. Id. at 35, 513 P.2d at 893, 109 Cal. Rptr. at 669.

81. See id. at 41, 513 P.2d at 897, 109 Cal. Rptr. at 673 (Tobriner, J., dissenting).

82. 2d Civ. No. 37942 (Cal. Ct. of App., 2d Dist., Div. 5, filed Dec. 17, 1971).

83. Id. at 8-9.

84. Id. at 9. 
was conducted. Physical location alone can provide no reliable guide to the tendency of an action to impair scliool relationships or performance.

More fundamentally, it seems doubtful that the Morrison standard can be met by using publicity or notoriety, by themselves, to prove unfitness to teacli. Scliool administrators wlio testify that public knowledge of the teaclier's conduct is likely to interfere with the teacher's ability to command respect liave great difficulty documenting the truth of this cliarge. ${ }^{85}$ Careful probing is necessary to be sure that school administrators seeking to predicate revocation on alleged notoriety are not simply voicing their own disapproval of the teaelier's conduct. ${ }^{86}$

Even in the rare case where scliool administrators can show that notoriety will harm sclool relationships, revocation slould not inevitably result. Even though it is shown that a teacler's aetions impair his teaching efficiency, the inquiry slould consider wliether the impairment is so severe as to override the teaclier's interest in continuing to practice his chosen profession and to live his personal life free from interference. A number of factors will be relevant to such a determination: the level or type of scliool, ${ }^{87}$ the age of the students, ${ }^{88}$ the subject tauglit, ${ }^{89}$ the likelihood that the act will be repeated, ${ }^{90}$ the recent-

85. See. e.g., Comings v. State Bd. of Educ., 23 Cal. App. 3d 94, 99-100, 100 Cal. Rptr. 73, 77 (1st Dist. 1972); Governing Bd. of Nicasio School Dist. v. Brennan, 18 Cal. App. 3d 396, 402, 95 Cal. Rptr. 712, 715-16 (1st Dist. 1971). But see Pettit, 10 Cal. 3d at 36, 513 P.2d at 893, 109 Cal. Rptr. at 669.

86. Morrison, of course, emphasized that school authorities have no power to dismiss a teacher simply because his personal, private conduct incurs their disapproval. 1 Cal. 3d at 225, 461 P.2d at 382, 82 Cal. Rptr. at 182. But cf. Pettit, 10 Cal. 3d at 35, 513 P.2d at 893, 109 Cal. Rptr. at 669 , where revocation was upheld although the court conceded that "expert" testimony inevitably reflects the personal bias of the witness.

87. In general, notoriety is likely to be less serious in large, metropolitan schools than in schools located in small, closely knit communities.

(a) Rumors are likely to proliferate less in big-city schools than in schools located in small towns where the private lives of teachers are the subject of great local interest.

(b) Even where rumors start, more sophisticated students are likely to give them less currency.

(c) Where the rumors, true or false, attain damaging proportions, big-city schools have an option not readily available to smaller schools: the teacher can be transferred to a distant school in the same district.

In close cases, one factor worth considering may be the teacher's special training and the community's need for exceptional skills. See Pettit, 10 Cal. 3d at 37, 513 P.2d at 894, 109 Cal. Rptr. at 670 (Tobriner, J., dissenting).

88. See McConnell v. Anderson, 316 F. Supp. 809, 814 (D. Minn. 1970): "Plaintiff's position [as a university librarian] will not expose him to children of tender years who conceivably could be influenced or persuaded to his penchant." But see Stubblefield, 16 Cal. App. 3d at 320, 94 Cal. Rptr. at 318, which held that a junior college instructor caught in a sexual act with a student was justifiably dismissed from his position.

89. See text accompanying note 66 supra.

90. Morrison, 1 Cal. 3d at 229, 461 P.2d at 386, 82 Cal. Rptr. at 186. 
ness or remoteness of the mcident, ${ }^{91}$ and the degree of the notoriety engendered by the conduct. ${ }^{92}$ In this step of the analysis, courts should insist upon a high standard of proof from the school district; a shightly discordant working atmosphere may be an acceptable price to pay for diversity and liberty, particularly in cases where the harm to the educational process is uncertain or speculative. ${ }^{93}$

\section{The Legality of the Conduct}

A second index by which courts have tried to measure the tendency of certain conduct to produce notoriety is its legality or illegality. Some courts, such as the court in Moser, have felt that a teacher's criminal conviction for a sex offense automatically justified dismissal. In distinguishing Morrison, Moser pointed out that Morrison had never been criminally charged for his single indiscretion, while Moser had been convicted of a crime. ${ }^{94}$ Moser had argued, relying on disbarment proceedings against attorneys, that conviction of a criminal offense by itself does not always constitute proof of unfitness. ${ }^{95}$ The court rejected his argument, insisting that "immoral" or "unprofessional" conduct be interpreted in the context of specific professions. ${ }^{96}$ Criminal convictions that might not warrant disbarment of an attorney, for example, could nevertheless warrant dismissal of a teacher charged with the care and education of young children. ${ }^{97}$

The court looked back nearly 50 years to Goldsmith $v$. Board of Education ${ }^{98}$ to find support for this distinction. In Goldsmith, the court wrote that the sensitive, fiduciary nature of a teacher's work made the speech, habits, reputation, and even the wisdom of a teacher's unofficial utterances matters of legitimate concern to his employer. ${ }^{99}$ While Goldsmith may, perhaps, be read as a model code of ethics for the teaching profession, even in that case the court conceded that the

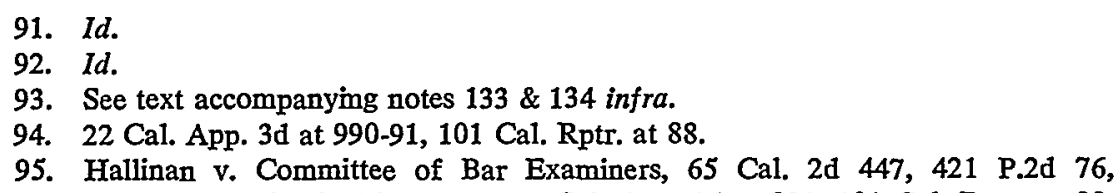
55 Cal. Rptr. 228 (1966), cited in Moser, 22 Cal. App. 3d at 991, 101 Cal. Rptr. at 88.

96. 22 Cal. App. 3d at 991, 101 Cal. Rptr. at 88. See also Morrison's comparison of justifications for disbarring an attorney to those for revoking a physician's medical certificate. 1 Cal. $3 d$ at 220-25, 461 P.2d at 379-82, 82 Cal. Rptr. 179-82.

97. 22 Cal. App. 3d at 991, 101 Cal. Rptr. at 88.

98. 66 Cal. App. 157, 168, 225 P. 783, 787 (3d Dist. 1924), cited in Moser, 22 Cal. App. 3d at 991, $101 \mathrm{Cal}$. Rptr. at 88.

99. $66 \mathrm{Cal}$. App. at 168, 225 P. at 787. See also Horenstein, Homosexuals in the Teaching Profession, 20 Clev. Sr. L. Rev. 125, 126 (1971). Goldsmith's language was criticized as "overly broad" in Morrison. 1 Cal. $3 \mathrm{~d}$ at 222-23 n.12, 461 P.2d at 381 n.12, 82 Cal. Rptr. at 181 n.12. 
required characteristics must bear some relation to ability to teach. ${ }^{100}$ Where-as will often be the case with private, consensual behavior with other adults-the actions bear no direct connection with teaching effectiveness, such a showing may well be impossible. Moreover, inasmuch as Goldsmith dealt with classroom conduct (advocating the election of a certain candidate to public office), ${ }^{101}$ its application to situations involving out-of-school acts resulting in misdemeanor convictions is questionable.

In Amundson v. State Board of Education, ${ }^{102}$ the court also weighed the criminality of the teacher's conduct. Unlike Moser, however, Amundson ruled that the Morrison standard could not be met simply by adverting to the criminal nature of the conduct. ${ }^{103}$ The court said that it is irrational to assert that fitness to teach depends on whether the legislature has chosen to outlaw one form of sexual behavior and not another. ${ }^{104}$ The court conceded, however, that if the publicity attending a conviction or prolonged absence due to a jail sentence affected a teacher's ability to carry out his duties, the Morrison test of job-relatedness might be satisfied. ${ }^{105}$ Apart from these situations, Amundson held that criminality that does not demonstrably affect ability to teach is irrelevant. ${ }^{108}$

The Pettit court, however, treated criminality as relevant to the dismissal decision. The court found in Morrison an implication that conviction of lesser sex offenses would furnish support for a finding of immoral or unprofessional conduct. ${ }^{107}$ However, the majority assumed, without examination, that criminality aids in resolving the fitness issue. Rather than focusing on Morrison's fitness standard in its discussion of criminality, ${ }^{108}$ Pettit merely quoted the statutory standards "immoral" and "unprofessional" conduct-the very terms Morrison held to be constitutionally sound only if confined to conduct that evidences unfitness to teach. Thus, in Pettit the court seems to have breathed new life into Sarac's notion of immorality as unfitness per se. Such a notion, of course, is inconsistent with Morrison's requirement of job-relatedness. In fact, as the district court of appeals decision in Pettit noted, if criminality alone were to be determinative the statutory distinction between the disciplinary consequences of crimes enumerated

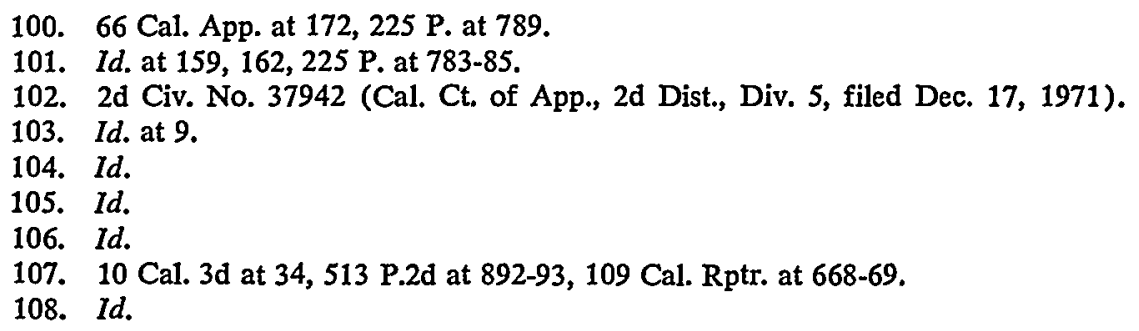


in the Education Code and crimes not enumerated would be obliterated. ${ }^{108}$

While in practice revocation is generally sought only against those whose sexual behavior becomes legally cognizable, there is little difference, for revocation purposes, between one who is caught and one who is not. If it is teaching effectiveness that the law seeks to promote and if revocation is not meted out as punishment but only to protect the school community, ${ }^{110}$ the legality or illegality of an imdividual's conduct, while perhaps a rough guide to its tendency to generate injurious publicity, can never be completely dispositive. Is it relevant to a determination of fitness to teach that Morrison engaged in homosexual inutual masturbation (legal) while Pettit performed heterosexual acts of oral copulation (illegal)? Certainly it would be strange if legality were sufficient to absolve Morrison and illegality to condemn Pettit when, if authorities are to be believed, ${ }^{111}$ it was Morrison who engaged in the more socially disapproved conduct. ${ }^{112}$ In sum, distinguishing conduct as legal or illegal provides relatively little help in determining whether a given individual is fit to teach.

\section{Notoriety and Its Effect on Students}

A number of courts ${ }^{13}$ and commentators ${ }^{114}$ have urged that teachers, because of the unique nature of their work, should be held to a higher standard of behavior than other professionals. Two variants of this argument are employed:

109. Pettit, 2d Civ. No. 39637, at 12 (Cal. Ct. of App.. 2d Dist., Div. 3, filed Sept. 28, 1972). See also Pettit, 10 Cal. 3d at 40, 513 P.2d at 896, 109 Cal. Rptr. at 672 (Tobriner, J., dissenting), where it is suggested that if criminality is thought to be important, misdemeanors of all kinds might automatically constitute "immoral" or "unprofessional" conduct. Justice Tobriner correctly reasoned that because a criminal conviction has no talismanic significance [Morrison, 1 Cal. 3d at 219 n.4, 461 P.2d at $378 \mathrm{n} .4,82 \mathrm{Cal}$. Rptr. at $178 \mathrm{n} .4$ ] "the nature of the conduct and its relation, if any, to the role and functions of the teacher" is the proper analytical approach. Pettit, 10 Cal. 3d at 40, 513 P.2d at 896, 109 Cal. Rptr. at 672.

110. See generally, Morrison, 1 Cal. 3d at 222, 461 P.2d at 380-81, 82 Cal. Rptr. at $\mathbf{1 8 0 - 8 1 .}$

111. See anthorities cited in notes 54 supra and 112 infra.

112. "According to expert sociological testimony it is now estimated that 75 percent to 80 percent of married women of appellant's age and educational level engage in oral stimulation of their mates' genitalia as a pre-coital technique." Pettit, 2d Civ. No. 39637, at 5 n.5 (Cal. Ct. of App., 2d Dist., Div. 3, filed Sept. 28, 1972), See also Pettit, 10 Cal. 3d at 40, 513 P.2d at 897, 109 Cal. Rptr. at 673 (Tobriner, J., dissenting).

113. See, e.g., Moser v. State Bd. of Educ., 22 Cal. App. 3d 988, 991, 101 Cal. Rptr. 86, 88 (2d Dist. 1972); Goldsmith v. Board of Educ., 66 Cal. App. 157, 168, 225 P. 783, 787 (3d Dist. 1924).

114. E.g., Horenstein, Homosexuals in the Teaching Profession, $20 \mathrm{ClEv}$. ST. L. Rev. 125 (1971). 
1) Teachers who engage in certain behavior will be unable to fulfill their duty to instill moral values in their students;

2) Teachers who practice nonconforming sexual behavior are likely to be emulated by impressionable students.

The first proposition derives support from section 13556.5 of the California Education Code which requires that teachers "endeavor to impress upon the minds of the pupils the principles of morality."115 Assuming this rather imprecise charge can be given defimite content, it would still seem possible that a teacher could comply with the statute even though he or she engaged in off-duty acts of sexual deviancy. In Pettit, for example, the court of appeals agreed with the trial court that the opinion of three administrators that the teacher could not teach morality if she did not herself practice sexual morality was entitled to hittle weight. ${ }^{116}$ The record simply did not suggest that the offending teacher had failed to carry out the statutory mandate. The contention, reminiscent of Sarac, that immoral conduct by itself implies an imability to comply with the Education Code was rejected. ${ }^{117}$ The California Supreme Court, however, felt that the administrators' testimony that Pettit would be "unable to teach moral principles" and set a proper example for her students justified disimssal and revocation of her teaching credential. ${ }^{118}$ The court apparently failed to note that the administrators offered no support for their opimions, and that during the two and one-half years between Pettit's escapade and her hear$\mathrm{mg}$, she had functioned as an effective teacher. ${ }^{110}$

The second basis for requiring teachers to conform to a higher moral standard in their personal lives than other professionals is that a teacher's sexual misconduct is apt to serve as an example of lawlessness or immorality that will be emulated by students. ${ }^{120}$ Assuming that nonconforming sexual experimentation is to be discouraged on the part of students and that dismissal of offending teachers may help to effectuate this goal, emulation can occur only if students become aware of intimate details of the teacher's sex life. Where the teacher sought publicity for his or her illegal conduct, ${ }^{121}$ or where the imisbehavior was featured in the popular media, ${ }^{122}$ students may have the knowledge

115. Cal. Educ. Code $\& 13556.5$ (West 1969).

116. 2d Civ. No. 39637, at 9-10 (Cal. Ct. of App., 2d Dist., Div. 3, filed Sept. 28, 1972).

117. Id. at 10 .

118. 10 Cal. $3 d$ at 36 n.7, 513 P. 2 d at 894 n.7, 109 Cal. Rptr. at 670 n.7.

119. $10 \mathrm{Cal}$. 3d at 30-31, 513 P.2d at 890,109 Cal. Rptr. at 666 .

120. See, e.g., cases cited in note 85 supra.

121. E.g., Governing Bd. of Nicasio School Dist. v. Brennan, 18 Cal. App. 3d 396, 95 Cal. Rptr. 712 (1st Dist. 1971).

122. E.g., Comings v. State Bd. of Educ., 23 Cal. App. 3d 94, 100, $100 \mathrm{Cal}$. Rptr. 73, 77-78 (1st Dist. 1972). 
of a teacher's personal life that could constitute him a role model. In the great majority of cases, however, students are unaware of and probably not even particularly concerned with their teachers' sexual preferences, and the need to remove a teacher as a model for sexual misconduct does not arise.

Some courts have thought the harm to students of a teacher's "public" sexual behavior flowed from the teacher's poor model, not of appropriate sexual conduct, but of respect for law and authority. In Stubblefield, for example, because the police had easily discovered the teacher's love tryst and because he had led them on a high-speed chase before being captured, the court felt the law-defying behavior had invited public attention. ${ }^{123}$ While the decision did not rest on a finding of notoriety, ${ }^{124}$ it is nevertheless strange that the circumstances surrounding the teacher's arrest were considered relevant. Since there was no showing that the behavior had come to the attention of students, it is unlikely that it had reduced Stubblefield's effectiveness as a model of appropriate behavior. Similarly, in Watson v. State Board of Education, ${ }^{125}$ the court of appeals held that convictions for public drunkenness and drunk driving demonstrated unfitness to teach since the public nature of the offenses proved that the teacher failed to set a good example of proper respect for law. ${ }^{128}$ Here again the court failed to consider whether students were aware, or were likely to become aware, of the offending conduct. As with criminality, the failure to show that notoriety supplied evidence of job unfitness, specifically fitness to model approved behavior, should have led the courts in Watson and Stubblefield to reject the notoriety arguments.

When knowledge of the unlawful or deviant behavior does come to the attention of students, two possibilities of harm exist: (1) the teacher will no longer be able to command the respect necessary to successful classroom management; ${ }^{127}$ (2) the teacher will stand as a model of behavior which, although condemned by the community, may be emulated by his students. ${ }^{128}$ The first threatens disruption of the educational process. The second might result in the schools being perceived as a threat to majoritarian values and standards of conduct.

Preserving discipline in the classrooin and the teacher as a model of prevailing sexual mores may, in soine circumstances, be interests that

123. 16 Cal. App. 3d at 826-27, 94 Cal. Rptr. at 322.

124. It appears that dismissal may have been justified on the ground that Stubblefield had been guilty of actual misconduct with a student, although this is not entirely clear from the opinion. Id. at 827, $94 \mathrm{Cal}$. Rptr. at 322-23.

125. 22 Cal. App. 3d 559, 99 Cal. Rptr. 468 (2d Dist. 1971).

126. Id. at $564,99 \mathrm{Cal}$. Rptr. at 472 .

127. Morrison, 1 Cal. 3d at 237, 461 P.2d at 392. 82 Cal. Rptr. at 192.

128. Id. at 247, 82 Cal. Rptr. at 200, 461 P.2d at 400 (Sullivan, J., dissenting). 
should be preferred over the right of the teacher to conduct his private life as he sees fit. A number of difficulties remain to be considered, however, before these possibilities of harm to the educational process can be accepted as sufficient grounds for credential revocation. First, none of the cases simce Morrison have succeeded in establishing that students' knowledge of a teacher's sexual behavior harms them in any tangible way. It is a possibility of harm, then, that must be balanced against the teacher's interest in continumg to practice his profession. When a possibility of harm can overcome a significant personal interest is not an easy question. The absence of empirical evidence that students do, or do not, emulate their teachers' sexual behavior makes resolution of the question even more difficult. Courts may be teinpted to prefer majoritarian sexual values rather than to resolve the issue in terms of fitness to teach. ${ }^{129}$

The fear that classroom discipline will decline is premised on a prediction that students will lose respect for a teacher whose sexual conduct is unorthodox. Studies do demonstrate that groups accept more willingly the suggestions of a leader whom they respect and admire. ${ }^{130}$ Observations of classrooin response to different teachers show that morale and discipline are highest in classes conducted by teachers whom the students regard as "good" teachers. ${ }^{131}$ These data suggest that students may not respond as well to teachers whose sexual preferences have offended the community as to teachers whose sex lives conform to a more conventional pattern.

Ultinately the weight to be given this argument depends on fundainental perceptions about the role of pluralism in the educational process. As was pointed out earber, ${ }^{132}$ a certain amount of "friction" may be inherent in a society or a school system that professes to follow the democratic ideal. Individuals with nonconforming values or modes of life always provoke anxiety, ${ }^{133}$ and occasionally hostility, in those around them. If this is imevitable, and even healthy, in a plurahistic society, there is much to be said for tolerating such expressions of individuality and diversity in the schools, which are the institutions charged with imculcating the value of diversity in future generations. In such a society, the ideal teacher may not mirror every accepted value, holding none up for examination or discussion of available alterna-

129. Reliance on majoritarian values was discredited in both Morrison and Norton. See text accompanying notes 71-73 supra.

130. See e.g., F. FIEDLER, LeAder ATtitudes AND GROUP EFfectiveness $42-45$

(1958); D. Latrd \& E. LaIrd, The New Psychology for Leadership 20-21 (1956).

131. Cf. S. Webster, Discipline In the Classroom, 36, 60-61 (1968).

132. See text accompanying note 93 supra.

133. See generally, D. Cartwrighr, Group Dynamics 82-85, 128-33 (1st ed. 1956). 
tives. ${ }^{134}$ A stable and competent teacher known by his students to follow a nonconforming sexual pattern might well have a legitimate role to play in the educational process.

\section{E. Student Perception of Teachers' Private Values}

Studies of creativity, still fragmentary and incomplete, suggest that a teacher's values, even if not made manifest, are capable of being unconsciously transmitted to his students. ${ }^{135}$ It could be argued that a teacher's sexual orientation might be similarly perceived and adopted by students, even without their awareness. The studies that suggest this result, however, are at best tentative ${ }^{136}$ and have never been duplicated with respect to sexual preferences. Because the teacher's interests in retaining his credentials are substantial, the inconclusive state of the scientific evidence argues against a finding that privately held and practiced values justify the dismissal of an otherwise dedicated and competent teacher.

\section{CONCLUSION}

On examining the several possible grounds for barring from the teaching profession persons who engage in disapproved forms of sexual behavior, only two survive: potential for misconduct with students, and the destructive effect of notoriety on the teaching environment. Unquestionably, teachers may be dismissed from the profession if it can be shown that they are likely to seduce or engage in forbidden sexual activity with their students. Similarly, teachers whose sexual escapades demonstrably impair their ability to command respect from their students or colleagues may be barred from teaching provided the notoriety is real rather than speculative and is shown to exist independently of the publicity surrounding the dismissal proceedings themselves.

Since teachers are traditionally regarded as the professional class responsible for transmitting cultural and ideological values essential to the preservation of society, decisions to retain or dismiss teachers for private conduct will always pose hard questions. In the emotion-laden

134. See Wieman v. Updegraff, 344 U.S. 183, $196-97$ (1952) (Frankfurter, J., concurring); Comment, The Good Moral Character of California Administrative Agencies-A Study of the Good Moral Chararter Requirement, 5 U.C. DAvis L. REv. 84, 101-03 (1972).

135. Turner \& Denny, Teacher Characteristics, Teacher Behavior, and Changes in Pupil Creativity, 69 ELEM. Sch. J. 265 (1969). See also Rosenthal, The Pygmalion Effect Lives, Psychology Today, Sept. 1973, at 56.

136. See generally Morgan \& Woerdehoff, Stability of Student Teacher Behaviors and their Relationships to Personality and Creativity Factors, 62 J. EDUC. RES. 251 (1969). 
atmosphere surrounding dismissal proceedings it is easy to succumb to the temptation of characterizing issues as black or white; as decency and morality on the one hand, or liberty and individuality on the other. Both sets of values are, of course, involved, but characterizing the level of preference so generally precludes ineaningful choice. This Comment demonstrates that only by rigorous application of the Morrison fitness-to-teach standard can both the teacher's interest in a private life free from undue scrutiny and the public's interest in protecting its schools adequately be served.

Robert E. Willett 